\title{
Chemical Constituents, Antibacterial Activity and Mode of Action of Elephant Ginger (Zingiber officinale var. officinale) and Emprit Ginger Rhizome (Zingiber officinale var. amarum) Essential Oils
}

\author{
Diki Prayugo Wibowo ${ }^{1}$, Ria Marianiं ${ }^{2}$, Siti Uswatun Hasanah', Diah Lia Aulifa ${ }^{1, *}$
}

Diki Prayugo Wibowo', Ria

Mariani $^{2}$, Siti Uswatun Hasanah', Diah Lia Aulifa ${ }^{1, *}$

'Department of Pharmaceutical Biology, Indonesian School of Pharmacy (Sekolah

Tinggi Farmasi Indonesia). Jl. Soekarno Hatta No. 354, Bandung, West Java, INDONESIA.

${ }^{2}$ Department of Pharmaceutical Biology,

Garut University. Jl. Jati 42, Garut, West Java, INDONESIA.

\section{Correspondence}

\section{Diah Lia Aulifa}

Department of Pharmaceutical Biology, Indonesian School of Pharmacy (Sekolah Tinggi Farmasi Indonesia). JI. Soekarno Hatta No. 354, Bandung, West Java, INDONESIA.

E-mail: diahliaaulifa@stfi.ac.id

History

- Submission Date: 02-12-2019;

- Review completed: 07-01-2020;

- Accepted Date: 26-01-2020.

DOI : 10.5530/pj.2020.12.62

Article Available online

http://www.phcogj.com/v12/i2

\section{Copyright}

(c) 2020 Phcogj.Com. This is an openaccess article distributed under the terms of the Creative Commons Attribution 4.0 International license.

\begin{abstract}
Introduction: Ginger (Zingiber officinale Rosc) is a spice plant, which is extensively used worldwide, and morphologically classified into three types, including the red, "gajah" or "elephant", and "emprit" ginger (common name in Indonesia). In addition, the extract and essential oils possess antibacterial pharmacological activities, due to the inherent constituents. The aim of this research, therefore, was to analyze the chemical constituents, test antibacterial activities, and observe the mode of action of elephant and emprit ginger rhizome essential oils. Methods: Essential oils isolation was conducted using water and steam distillation method, while microdilution method was adopted in the testing for antibacterial activities against Gram positive and negative bacteria. Furthermore, the mode of action was evaluated using Scanning Electron Microscopy (SEM). Results: The antibacterial activity demonstrated antibacterial activities in the essential oils of elephant and emprit ginger rhizome, with minimal inhibition concentrations (MIC) value of $250-1000 \mu \mathrm{g} \cdot \mathrm{mL}^{-1}$ and minimal bacterial concentrations (MBC) value of 500-1000 $\mu \mathrm{g} \cdot \mathrm{mL}^{-1}$, while chemical evaluation showed the presence of 45 and 38 constituents, respectively. Conclusion: Both essential oils possess antibacterial activities against Gram positive and negative bacteria, with different strengths, which are based on chemical composition. Conversely, SEM micrographs demonstrated the ability for elephant and emprit ginger rhizome essential oils to change the morphology of bacteria.

Key words: Antibacterial, Elephant ginger, Emprit ginger, Chemical constituents.
\end{abstract}

\section{INTRODUCTION}

Ginger (Zingiber officinale Rosc) is a spice plant, which is extensively used worldwide, and is morphologically classified into three types, including the red, gajah or elephant and emprit ginger. ${ }^{1}$ These tend to differ from one another in terms of shape, color, odor, and chemical constituents. Specifically, the elephant variety possesses a huge rhizome, less odor and fiber, while the red has a relatively smaller rhizome, red skin, sharp odor and more fiber. Conversely, Emprit ginger has small rhizome, beige skin color with sharp odor and more fiber. ${ }^{1}$

Traditionally, ginger has been used in the treatment of cold, digestion disorder, pain, fever, inflammation, and others. ${ }^{2}$ However, the extract scientifically possesses pharmacological activities, including antidiarrheal, based on the inhibitory effect of B-FITC toxin, on the receptor binding mechanism at a concentrations of 25 and $50 \mu \mathrm{g} /$ ml. ${ }^{3}$ In addition, antidiabetic, ${ }^{4}$ anticonvulsion, ${ }^{5}$ antinausea, ${ }^{5}$ antibacterial, ${ }^{6,7}$ lipid decreasing ${ }^{8,9}$ and anti-inflammatory ${ }^{10}$ effects have also being exploited with the essential oils of ginger, e.g., Zingiber striolatum. Specifically, the antimicrobial activity recorded in prior studies show a minimal inhibition concentration (MIC) value of 0.78 $3.12 \mathrm{mg} / \mathrm{mL}$, anticancer effect was reported for leukemia (K562), cervical (A549), and prostate (PC3) cancers, with IC $_{50}$ value of $29.67 ; 48.87 ; 86.05 \mu \mathrm{g} /$ $\mathrm{ml}$, respectively. ${ }^{11}$

Pharmacology activities of ginger essential oils depend on the inherent chemical composition. The aim of this research, therefore, was to analyze the chemical constituents, test antibacterial activities, and observe the mode of action of elephant and emprit ginger rhizome essential oils.

\section{MATERIALS AND METHODS}

\section{Plant material}

The rhizomes of elephant and emprit ginger were collected from Balai Penelitian Tanaman Rempah dan Obat (BALITTRO), Bogor, Jawa Barat, and determined at Jatinangor Herbarium, Taxonomy laboratory, Biology faculty, Padjadjaran university, with specimen number $123 / \mathrm{HB} / 03 / 2018$. Therefore, soil and others were cleaned from the fresh specimen, using water flow, and chopped to $2 \mathrm{~mm}$ thickness after draining.

\section{Isolation of essential oil}

The isolation of essential oils was conducted using water and steam distillation method for 3 hours, and both samples were then stored in the refrigerator prior to further analysis.

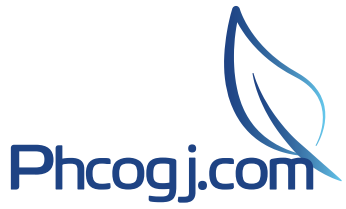

Cite this article: Wibowo DP, Mariani R, Hasanah SU, Aulifa DL. Chemical Constituents, Antibacterial Activity and Mode of Action of Elephant Ginger (Zingiber officinale var. officinale) and Emprit Ginger Rhizome (Zingiber officinale var. amarum) Essential Oils. Pharmacog J. 2020;12(2):404-9. 


\section{Gas chromatography-mass spectrometry (GC-MS) analysis}

The chemical constituent of elephant and emprit ginger essential oils were analyzed with GC (Shimadzu GCMS-QP2010 Ultra). Furthermore, the system temperature was initiated at $60^{\circ} \mathrm{C}$, and subsequently raised to $280^{\circ} \mathrm{C}$ at the injector. The detector used helium as eluent, at a 1.31 $\mathrm{ml} /$ minutes flow rate, $80.2 \mathrm{kPa}$ pressure, and $1.7 \mathrm{~cm} / \mathrm{sec}$ linear speed. Moreover, the MS system had a source temperature of $230^{\circ} \mathrm{C}$ and a 0.80 $\mathrm{KV}$ detector.

\section{Antibacterial activity}

Antibacterial tests was conducted by the microdilution methods, using Staphylococcus aureus ATCC6538, Bacillus subtilis ATCC6633 Bacillus cereus ATCC11778, Methicillin-resistant Staphylococcus aureus (MRSA) as positive gram bacteria and Pseudomonas aeruginosa ATCC9027, Escherichia coli ATCC8939 as negative bacteria. Furthermore, all microorganisms were obtained from the Microbiology Laboratory, Bandung Technology Institute, and the procedures were performed according to the National Committee for Clinical Laboratory Standard.

\section{Mode of action}

The mode of action for both essential oils were observed using Scanning Electrons Microscopy (SEM) at the Mineral Faculty Laboratory, Bandung Technology Institute, using the procedure stipulated by Anam. ${ }^{12,13}$

\section{RESULTS}

\section{Chemicals constituent of elephant and emprit ginger essential oils}

The chemical constituents of both samples were analyzed and the results showed the existence of differences between elephant essential oil, which contains 45 components, including 1,8-Cineole (6.4\%), arcurcumene $(2.75 \%)$, camphene $(6.48 \%)$, citral $(16.19 \%)$, fernesene (3.8\%), linalool (2.57\%), methylheptenone (2.33\%), sabinene $(6.19 \%)$, $\mathrm{z}$-citral (11.84\%), $\alpha$-cedrena (4.72\%), $\alpha$-pinen (3.22\%), $\beta$-bisabolene (2.28\%), $\beta$-myrcene $(2.48 \%)$ as well as $\beta$-sesquiphellandrene $(3.35 \%)$, and the Emprit variety, which consist of 38 chemical constituents, encompassing 1,8-Cineole (7.95\%), 1,8-p-methandiene (2.74\%), arcurcumene $(6.86 \%)$, Bornyl acetate $(3.21 \%)$, camphene $(10.14 \%)$, citral (16.19\%), geranyl acetate $(2.24 \%)$, methylheptenone (2.44\%), z-citral (12.23\%), $\alpha$-pinen (2.5\%), and $\beta$-bisabolen (2.64\%). Furthermore, Table 1 shows the chemical constituents of both samples.

\section{Antibacterial activities}

The test for antibacterial activity in both samples provided positive results, as shown by the MIC and MBC values, which was more potent in the elephant essential oil. This variety inhibited the growth of 5 bacteria, including Staphylococcus aureus, Bacillus subtilis, Bacillus cereus, Escherichia coli, and MRSA, while the emprit ginger prevented the growth of 3 species, encompassing Staphylococcus aureus, Escherichia coli, and MRSA. Table 2 shows MIC and MBC of both samples.

Table 2 demonstrates that the strongest inhibition of growth by both essential oils occurred with Staphylococcus aureus at $250 \mu \mathrm{g} \cdot \mathrm{mL}^{-1}$ MIC. Therefore, the mode of bacteria damage action was observed using Scanning Electron Microscopy (SEM). Figures 1 and 2 show SEM results.

\section{DISCUSSION}

There was a difference in the components and concentrations between elephant and emprit ginger essential oil. The main component also varied between the samples evaluated and as seen in study by Noori $(2018)^{14}$ and Sharma $(2016)^{15}$, the main component of ginger essential oils was a-zingiberene, while the main component in the sample is

Table 1: Chemical Constituent of Ginger Essential Oils.

\begin{tabular}{|c|c|c|c|}
\hline No & Chemical constituent & Elephant ginger (\%) & Emprit ginger (\%) \\
\hline 1 & (-)-Spathulenol & & 0.44 \\
\hline 2 & 1,8-Cineole & 6.4 & 7.95 \\
\hline 3 & 1,8-p-Menthadiene & & 2.74 \\
\hline 4 & 2-Heptanone & 0.21 & 0.19 \\
\hline 5 & 2-Nonanone & 0.95 & 1.21 \\
\hline 6 & 2-Undecanone & 1.84 & 1.54 \\
\hline 7 & 4-Terpineol & 0.88 & \\
\hline 8 & 4a-Methyl-trans-2-decalinone & & 0.46 \\
\hline 9 & ar-Curcumene & 2.75 & 6.86 \\
\hline 10 & Bornyl acetate & 0.63 & 3.21 \\
\hline 11 & Bornyl methyl ether & & 0.18 \\
\hline 12 & Camphene & 6.48 & 10.14 \\
\hline 13 & Camphor & 0.45 & 1.31 \\
\hline 14 & Caryopilen & & 0.42 \\
\hline 15 & Citral & 16.19 & 16.19 \\
\hline 16 & Citronella & 1.31 & 0.47 \\
\hline 17 & Citronellyl acetate & 0.27 & 0.51 \\
\hline 18 & Cryptone & 0.4 & 0.5 \\
\hline 19 & Cyclohexane & & 1.27 \\
\hline 20 & Cycloisolongifolene & 0.31 & \\
\hline 21 & d-3-Carene & 0.26 & \\
\hline 22 & d-Nerolidol & & 0.52 \\
\hline 23 & Farnesene & 3.8 & \\
\hline 24 & y-Cadinene & & 0.64 \\
\hline 25 & Geranic acid & & 1.51 \\
\hline 26 & Geraniol formate & & 0.46 \\
\hline 27 & Geranyl acetate & 0.68 & 2.24 \\
\hline
\end{tabular}




\begin{tabular}{|c|c|c|c|}
\hline 28 & Germacrene & 0.35 & \\
\hline 29 & y-Maaliene & 0.95 & \\
\hline 30 & Isoborneol & 0.58 & \\
\hline 31 & Isogeraniol & & 0.55 \\
\hline 32 & Linalool & 2.57 & \\
\hline 33 & Methylheptenone & 2.33 & 2.44 \\
\hline 34 & Myrtenal & & \\
\hline 35 & n-Decanal & 2.2 & \\
\hline 36 & Neoallocimene & 0.28 & \\
\hline 37 & p-Cymene & 0.29 & 0.56 \\
\hline 38 & Piperitenone & 0.32 & \\
\hline 39 & Piperitone & & 0.25 \\
\hline 40 & Sabinene & 6.19 & \\
\hline 41 & Squalene & & 0.27 \\
\hline 42 & Sylvestrene & & \\
\hline 43 & Thiogeraniol & 0.31 & 0.36 \\
\hline 44 & Tricyclene & 0.32 & 0.4 \\
\hline 45 & Valencene & 0.32 & \\
\hline 46 & Z-Citral & 11.84 & 12.23 \\
\hline 47 & Zingiberene & 0.07 & 0.22 \\
\hline 48 & a-Bergamotene & 0.28 & \\
\hline 49 & a-Cedrene & 4.72 & \\
\hline 50 & $\alpha$-Cubebene & 0.21 & \\
\hline 51 & $\alpha$-Guaiene & 0.24 & \\
\hline 52 & a-Phellandrene & 0.53 & \\
\hline 53 & a-pinene & 3.22 & 2.5 \\
\hline 54 & a-Terpineol & 2.24 & \\
\hline 55 & $\alpha$-Terpinolene & 0.64 & \\
\hline 56 & $\beta$-Bisabolene & 2.28 & 2.64 \\
\hline 57 & $\beta$-Elemene & 0.5 & 0.21 \\
\hline 58 & $\beta$-Myrcene & 2.48 & 1.09 \\
\hline 59 & $\beta$-Pinene & 0.87 & 0.49 \\
\hline 60 & $\beta$-Sesquiphellandrene & 3.35 & 0.4 \\
\hline
\end{tabular}

Table 2: MIC and MBC value of ginger essential oil against test bacteria.

\begin{tabular}{|c|c|c|c|c|c|c|c|}
\hline Essential oils & $\begin{array}{c}\text { Inhibition ( } \mu \mathrm{g} . \\
\mathrm{mL}^{-1} \text { ) }\end{array}$ & E. coli & P.aeruginosa & B.cereus & B.subtilis & S.aureus & MRSA \\
\hline \multirow{2}{*}{ Elephant ginger } & MIC & 500 & - & 1000 & 1000 & 250 & $>1000$ \\
\hline & $\mathrm{MBC}$ & 500 & - & $>1000$ & - & $>1000$ & - \\
\hline \multirow{2}{*}{ Emprit ginger } & MIC & 1000 & - & - & - & 250 & 1000 \\
\hline & MBC & $>1000$ & - & - & - & $>1000$ & $>1000$ \\
\hline
\end{tabular}

Citral. These differences are possibly influenced by the location of the growing plant, time of harvest, plant genetics and other factors. Furthermore, the statement is supported by the research of Bhattarai, ${ }^{16}$ which stipulated the existence of variation in components amongst three types of ginger grown in different location.

The chemical component is the determinant of antibacterial activity, exhibited by the sabinen, $\alpha$-pinen, $\beta$-pinen, $\beta$-phellandrene, $\gamma$-elemene, $\delta$-elemene, $\beta$-caryophyllene, $\gamma$-caryophyllene, and germacrene $B$ content. ${ }^{17-21}$ These were all identified in the elephant ginger variety, making it a comparably better antibacterial agent, due to the ability to inhibit the growth of all test bacteria, including the Gram positive. Conversely, emprit ginger only restrained the growth of 2 microorganisms (E. coli and S. aureus), while a research by El-baky $(2010)^{22}$ showed the specific inhibitory activity of $\beta$-sesquiphellandrene, caryophyllene and zingiberene against the growth of Gram positive bacteria. These components, however, tend to be more available in the elephant ginger essential oil.

SEM micrograph (Figure 1 and Figure 2 A-C) showed the normal Staphylococcus aureus cell as circular in shape with smooth surface, which were modified after growth in the presence of elephant and emprit ginger essential oils, as well as Amoxicillin. This drug is known to act by binding to penicillin-binding proteins, which inhibit a transpeptidation process, therefore leading to the activation of autolytic enzymes in the bacterial cell wall, followed by lysis. ${ }^{23}$ Based on previous research, damage of bacteria has been affiliated with interactions between essential oil and enzyme, as well as the protein membrane, ${ }^{24-26}$ as the chemical constituents penetrate the cellular bilayer membrane. This leads to increased permeability, and the subsequent leakage. ${ }^{24-26}$ 

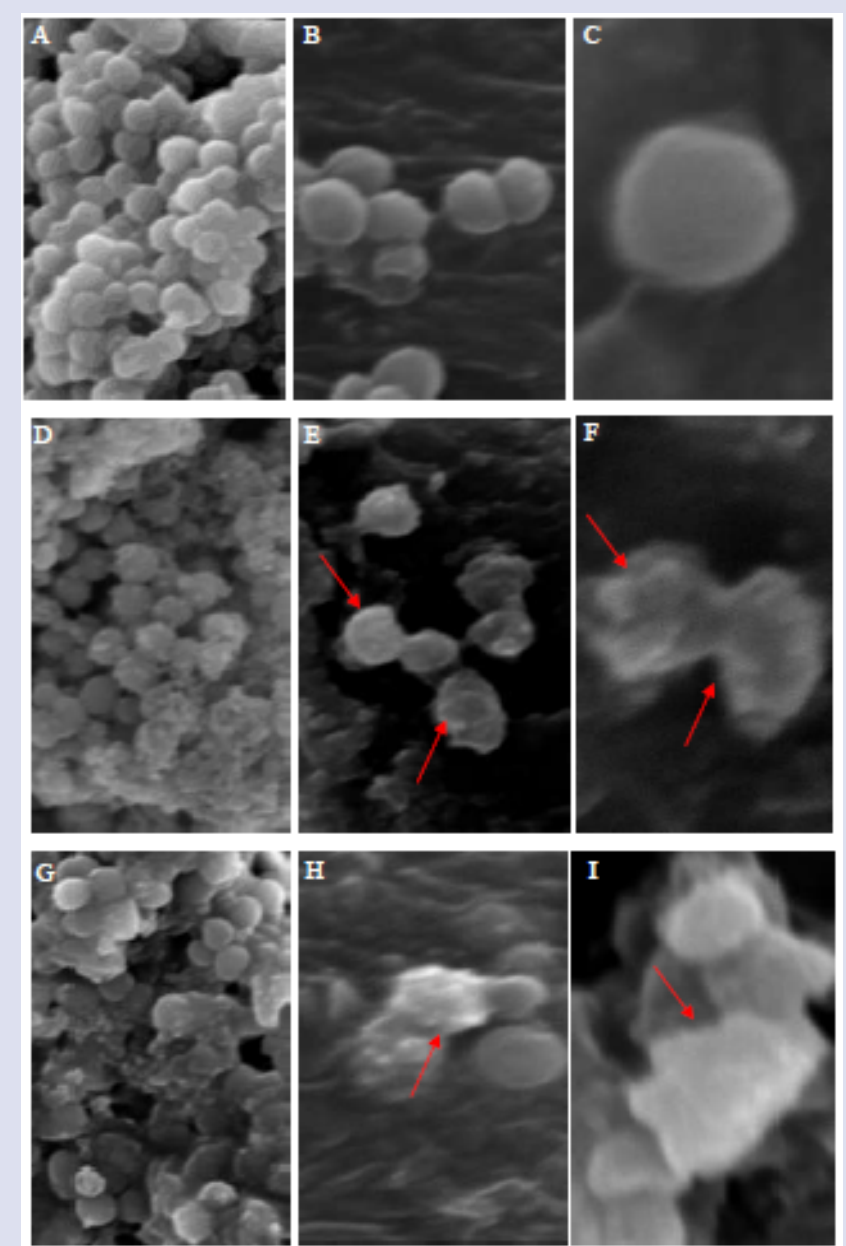

Figure 1: SEM micrograph of S. aureus (A-C) Control, (D-F) after growth in the presence of $1000 \mu \mathrm{g} \cdot \mathrm{mL}^{-1}$ emprit ginger essential oils, (G-I) after growth in the presence of $20 \mu \mathrm{g} \cdot \mathrm{mL}^{-1}$ Amoxicilin. Red arrows show morphology changes.

\section{CONCLUSION}

Based on the results and discussion, elephant and emprit ginger essential oils possess antibacterial activity against Gram positive and negative bacteria, at a strength that is determined by the chemical constituents. In addition, SEM micrograph showed modification in bacteria morphology, following a treatment with both samples.

\section{ACKNOWLEDGMENTS}

The authors are grateful to Balai Penelitian Tanaman Rempah dan Obat (BALITTRO), Bogor, West Java for providing the ginger essential oils, as well as the Microbiology laboratory, Bandung Technology Institute for bacterial cultures, and Hazanah Foundation, Indonesian School of Pharmacy, through the Fundamental Research Grant number 009/SPK/ YHZ/II/2019 for the support and funding made available for this study.

\section{REFERENCES}

1. Wahyuni S, Bermawie N, Tsunematsu H, Ban T. Skrining Issr Primer Studi Pendahuluan Kekerabatan Antar Jahe Merah, Jahe Emprit Dan Jahe Besar. Bul Penelit Tanam Rempah dan Obat. 2015;15(1):33-42.

2. Winarti $C$, Nurdjanah N. Peluang tanaman rempah dan obat sebagai sumber pangan fungsional. J Litbang Pertan. 2005;24(12):47-55

3. Radiati LE, Nabet P, Franck P. Effect of Ginger (Zingiber officinale Roscoe) Dichloromethane Extract on Inhibition of Cholera Toxin B-subunit Conjugated FITC Binding to Receptor on LV Hibridome and Caco-2 Cells. J Teknol dan Ind Pangandan Ind Pangan. 2003;XIV(1):1-14
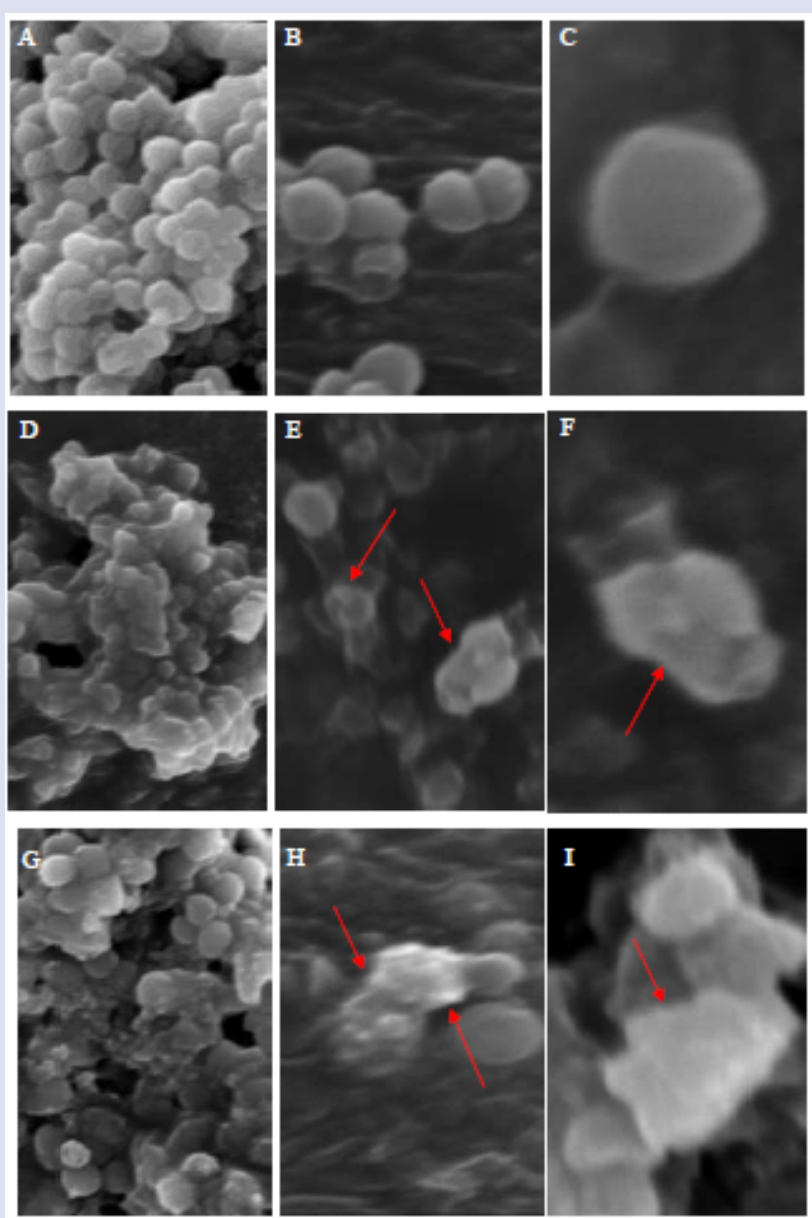

Figure 2: SEM micrograph of S. aureus (A-C) Control, (D-F) after growth in the presence $1000 \mu \mathrm{g} \cdot \mathrm{mL}^{-1}$ of elephant ginger essential oils, (G-I) after growth in the presence of $20 \mu \mathrm{g} . \mathrm{mL}^{-}$Amoxicilin. Red arrows show morphology changes.

4. Akhani SP, Vishwakarma SL, Goyal RK. Anti-diabetic activity of Zingiber officinale in streptozotocin-induced type I diabetic rats. J Pharm Pharmacol. 2004;56(1):101-5

5. Vishwakarma SL, Pal SC, Kasture VS, Kasture SB. Anxiolytic and antiemetic activity of Zingiber officinale. Phyther Res. 2002;16(7):621-6.

6. Khashan A. In vitro antibacterial activity of Zingiber officinale against pathogenic bacteria. Asian Pac J Trop Biomed Asian Pacific J Trop Biomed J homepage. 2018;2(5):72-5

7. Mohammed WF, Saleh BH, Ibrahim RN, Hassan MB. Antibacterial Activity of Zingiber officinale (Ginger) against Clinical Bacterial Isolates. South Asian J Res Microbiol. 2019;3(2):1-7.

8. Carnuta MG, Deleanu M, Barbalata T. Zingiber officinale extract administration diminishes steroyl-CoA desaturase gene expression and activity in hyperlipidemic hamster liver by reducing the oxidative and endoplasmic reticulum stress. Phytomedicine. 2018;48:62-9.

9. Nazish I, Ansari SH, Arora P, Ahmad A. Antiobesity activity of Zingiber officinale. Pharmacogn J. 2016;8(5):440-6.

10. Ezzat SM, Ezzat MI, Okba MM, Menze ET, Abdel-Naim AB. The hidden mechanism beyond ginger (Zingiber officinale Rosc.) potent in vivo and in vitro anti-inflammatory activity. J Ethnopharmacol. 2018;214:113-23.

11. Tian M, Liu T, Wu X. Chemical composition, antioxidant, antimicrobial and anticancer activities of the essential oil from the rhizomes of Zingiber striolatum Diels. Nat Prod Res. 2019;0(0):1-5

12. Anam K, Suganda A., Sukandar E., Broto L. Antibacterial Effect of Component of Terminalia muelleri Bent. against Staphylococcus aureus. Int J Parmacoloy. 2010;6(4):407-12.

13. Aulifa DL, Fitriansyah SN, Ardiansyah SA, Wibowo DP, Julata YA, Christy DS Phytochemical screening, antibacterial activity, and mode of action on Morus nigra. Pharmacogn J. 2018;10(1). 
14. Noori S, Zeynali F, Almasi H. Antimicrobial and antioxidant efficiency of nanoemulsion-based edible coating containing ginger (Zingiber officinale) essential oil and its effect on safety and quality attributes of chicken breast $\mathrm{fi}$ llets. Food Control. 2018;84:312-20.

15. Sharma PK, Singh V, Ali M. Chemical composition and antimicrobial activity of fresh rhizome essential oil of zingiber officinale roscoe. Pharmacogn $\mathrm{J}$. 2016;8(3):185-90

16. Bhattarai K, Pokharel B, Maharjan S, Adhikari S. Chemical Constituents and Biological Activities of Ginger Rhizomes from Three Different Regions of Nepal. J Nutr Diet Probiotics Res. 2018;1(1):1-12.

17. Cha JD, Jeong MR, Jeong SI, Moon SE, Kil BS, Yun SI, et al. Chemical composition and antimicrobial activity of the essential oil of Cryptomeria japonica. J Korean Orient Med Ophthalmol Otolaryngol Dermatologi. 2006;19(3):68-74

18. Sivasothy Y, Chong WK, Hamid A, Eldeen IM, Sulaiman SF, Awang K. Essentia oils of Zingiber officinale var. rubrum Theilade and their antibacterial activities. Food Chem. 2011;124(2):514-7.

19. Adio AM. Germacrenes A - E and related compounds : thermal , photochemical and acid induced transannular cyclizations. Tetrahedron. 2009;65(8):1533-52.
20. Bahi A, Al S, Al E, Al M, Nurulain SM, Ojha S. Physiology \& Behavior $\beta$ -Caryophyllene, a CB 2 receptor agonist produces multiple behavioral changes relevant to anxiety and depression in mice. Physiol Behav. 2014;135:119-24.

21. Zhu T, Xu Y, Dong B. B-Elemene Inhibits Proliferation of Human Glioblastoma Cells Through the Activation of Glia Maturation Factor B and Induces Sensitization To Cisplatin. Oncol Rep. 2011;26(2):405-13.

22. El-baky HHA Farag RS Saleh MA Characterization of antioxidant and antimicrobial compounds of cinnamon and ginger essential oils. African $J$ Biochem Res. 2010;4(6):167-74.

23. Kaur SP, Rao R, Nanda S. Amoxicillin: A broad spectrum antibiotic. Int J Pharm Pharm Sci. 2011;3(3):30-7

24. Burt SA, Reinders RD. Antibacterial activity of selected plant essential oils against Escherichia coli O157 : H7. Lett Appl Microbiol. 2003;36:162-7.

25. Kim J, Marshall MR, Wei C. Antibacterial Activity of Some Essential Oi Components against Five Foodborne Pathogens. J Agric Food Chem. 1995;43:2839-45.

26. Seydim AC, Sarikus G. Antimicrobial activity of whey protein based edible films incorporated with oregano, rosemary and garlic essential oils. Food Res Int 39 $2006 \cdot 39 \cdot 639-44$

\section{GRAPHICAL ABSTRACT}

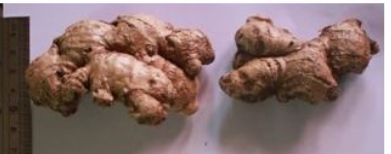

Emprit Ginger

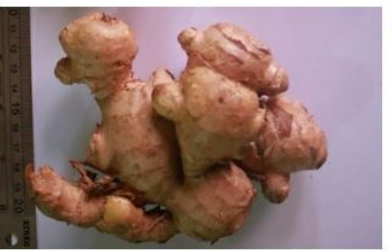

Elephant Ginger
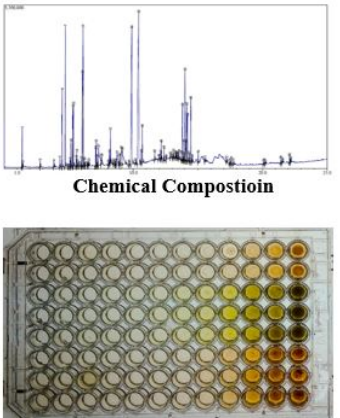

Determination of MIC and MBC

Essential Oil
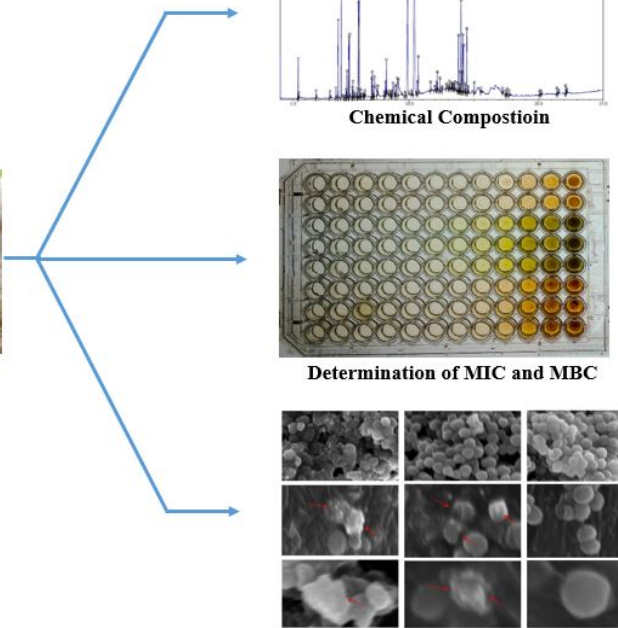
aureus with Scanning Electron Microscopy (SEM)

\section{ABOUT AUTHORS}

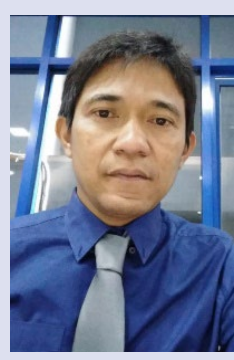

Diki Prayugo Wibowo is a lecturer in department of Pharmaceutical Biology, Sekolah Tinggi Farmasi Indonesia (Indonesian School of Pharmacy), Bandung-Indonesia, in the area concentration Phytochemistry and Microbiology.

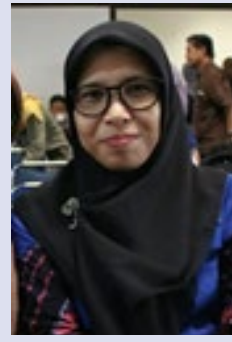

Ria Mariani is a lecturer in department of Pharmaceutical Biology, Garut University, Garut-Indonesia. Current research interests are Pharmacognosy, Phytochemistry, and Microbiology. 


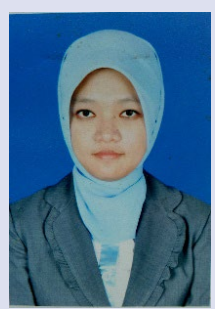

Siti Uswatun Hasanah is a lecturer in department of Pharmaceutical Biology, Indonesian School of Pharmacy, Bandung-Indonesia. Current research interests are Pharmacognosy and Natural Product Standardization.

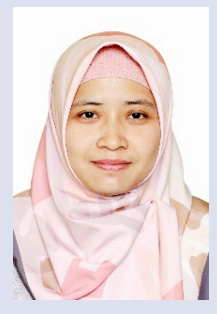

Diah Lia Aulifa is a lecturer in department of Pharmaceutical Biology, Indonesian School of Pharmacy, BandungIndonesia. Develop work in Phytochemistry and Phytotherapy from plants.

Cite this article: Wibowo DP, Mariani R, Hasanah SU, Aulifa DL. Chemical Constituents, Antibacterial Activity and Mode of Action of Elephant Ginger (Zingiber officinale var. officinale) and Emprit Ginger Rhizome (Zingiber officinale var. amarum) Essential Oils. Pharmacog J. 2020;12(2):404-9. 